\title{
Recreating and Materializing Social Differences through Patina-oriented Consumption: The Post-socialist Ownership History of a Second-hand, Luxury Commodity ${ }^{*}$
}

\author{
Péter Berta
}

\begin{abstract}
The study examines the post-socialist ownership history of an extremely valuable Gabor Roma prestige object: a silver-footed beaker. The resulting object biography sheds light on the role of the prestige economy constructed around silver objects in the creation, materialization, and renegotiation of social differences among the Gabor Roma in Romania. The analysis also reveals that this economy is a contemporary, second-hand culture based on patina-oriented consumption, similar to other economies of inalienable possessions (family heirlooms, etc.) or communities of competing collectors specializing in personal belongings of celebrities. The object biography further demonstrates how the second-handedness and ownership history of silver prestige objects are constructed through various ideologies and practices (sale, inheritance, economic brokerage, proprietary contests, etc.). Finally, the study makes a detailed comparison of the patina-oriented versus the fashion or novelty-oriented prestige goods popular among the Gabor Roma. The two can be distinguished from each other primarily by the different meanings and values associated with the ownership histories outlined in the introduction.
\end{abstract}

[Keywords: object biography; ownership history; prestige consumption, status mobility, Romanian Gabor Roma. Keywords in italics are derived from the American Folklore Society Ethnographic Thesaurus, a standard nomenclature for the ethnographic disciplines.]

\section{Introduction: Ownership History as a Value-increasing versus Value-reducing Factor: Patina- versus Novelty-oriented Consumption}

Although the symbolic boundary separating second-hand goods from new may vary across social contexts and it is often left subjective and vague, there is-as also noted by Setiffi (2011:12) — one criterion of second-hand status commonly adopted in both professional and everyday discourses. This states that the distinguishing feature of second-hand goods is that they have been owned by another person before regardless of whether the previous owner used them according to their purpose or not. (Let us leave out of consideration the manufacturers of the goods and the retailers selling them as owners.) In what follows, I shall combine Kopytoff's (1986) concept of object biography and McCarcken's (1986) definition of patina and treat object ownership history (the identity and memory of previous owners) as a marker and representation

\footnotetext{
* This peer-reviewed contribution was accepted for publication in Museum Anthropology Review on June 1, 2015. The work is licensed under the Creative Commons Attribution 4.0 International License. To view a copy of this license, visit http://creativecommons.org/licenses/by/4.0/
} 
of second-handedness. I shall consider it as the symbolic patina of the goods.

In order to understand the significance of ownership history as a symbolic property affecting consumption, let us consider the concept of "extended self," which was introduced by Belk (1988) in connection with the analysis of interactions between consumer goods and identities. From the point of view of understanding the effects of commodities on the lives of their owner (i.e., their agency) Belk (1988:139) considers it crucial to recognize that

knowingly or unknowingly, intentionally or unintentionally, we regard our possessions as parts of ourselves. As Tuan argues, 'Our fragile sense of self needs support, and this we get by having and possessing things because, to a large degree, we are what we have and possess' $(1980$, p. 472). That we are what we have...is perhaps the most basic and powerful fact of consumer behavior...possessions are an important component of sense of self.

The objects we posses, Belk continues (see also Gell 1998), can literally extend the limits of our self and agency. This is what happens, for instance, when "a tool or weapon allows us to do things of which we would otherwise be incapable" (Belk 1988:145). In several cases, we also define our possessions-such as various collections, pets or family heirlooms-as an extension of ourselves in a metaphorical sense (i.e., we regard them as an embodiment or materialization of our personality the loss of which would be a very sensitive issue and a source of great pain). There is no reason to doubt the accuracy of Belk's argument, that "the functions that possessions play in the extended self involve the creation, enhancement, and preservation of a sense of identity. Possessions help us at all ages to know who we are" (Belk 1988:150).

I argue that not only rare and in-demand objects themselves-the possessions of celebrities and other famous people-but also their ownership histories can be seen as a dimension of the owner's "extended self." Ownership histories are often regarded as symbolic pantheons-halls of fame-providing an opportunity for the consumers to construct, reproduce, and represent their identities. They can also serve as a means and context of the politics of difference. They allow the owner, for instance, to conspicuously advertise the economic and other resources accumulated, and provide an opportunity for invidious comparison between the new buyer and (1) the previous possessors who had no choice but to sell the object or (2) the rivals over whom the new buyer triumphed in the contest for the piece.

In recent decades the focus of consumption studies has partially shifted to counterbalance the dominance of analyses dealing with the acquisition of new commodities and its social impact. As a result of this process, an increasing number of researchers have raised the question of what happens to the goods after they have been deemed unsuitable for further use (Lastovicka and Fernandez 2005:813; Parsons and Maclaran 2009:301). Focusing on this question, several studies have devoted special attention to the various ways (gifting, selling, etc.) and contexts (flea-markets, garage-sales, charity shops, auctions, etc.; see Cheetham 2009; Gregson and Crewe 2003; Herrmann 2004) of disposing of second-hand commodities, the rituals accompanying their sale, the functions and impacts of these rituals on consumer identities (Belk 1988; 1995; Gregson and Crewe 2003; Lastovicka and Fernandez 2005; McCracken 1986; 
Strahilevitz and Loewenstein 1998), and how the symbolic properties (meanings, functions and the values) associated with second-hand goods are transformed in the process of recycling (Newman et al. 2011) or withdrawal from use (Gregson 2011; Miller and Parrott 2009).

As has been noted by several researchers, potential buyers may display a variety of attitudes towards the ownership history of second-hand goods. Two of these are discussed below.

\section{The Symbolic Patina of Second-hand Commodities - the Ownership History-as a Pollution to be Removed}

Some of these researchers warn that several consumers associate the purchase of second-hand goods with a negative meaning (low purchasing power; forced substitution for new goods; potential risks of previous use: physical and symbolic polution, etc.) and regard second-hand goods as objects that have suffered devaluation and remain undesirable. Due to these negative associations, when second-hand goods are put up for sale it is not uncommon to manipulate the biography of the piece and, as far as possible, to conceal the traces of its previous use. Let us call this attitude towards the value and meaning of goods (previous ownership = a negatively defined symbolic property that leads to loss of value and should thus be hidden) novelty-seeking or fashion-oriented consumption, which prefers the purchase of new commodities following the current fashion, and regards this choice as a morally respectable and valued consumer decision.

Explanations rationalizing the decrease in value and negative meanings associated with secondhand goods often refer to the alteration in material properties (wear and tear, etc.) and negative associations attached to previous-known or unknown-owners (i.e., the risks of the contact with them through the commodities: the risks of physical and symbolic pollution). This includes, for instance, possible diseases, misfortunes deriving from resale due to the death of the previous owner.

Thus, those purchasing second-hand commodities often employ meaning-eliminating and depersonalizing practices (or divestment rituals) which "rely on the consumer's historical and geographical imagination, about who has owned, used and worn the commodity before, when, where and under which conditions" (Gregson and Crewe 2003:144). They do this in the hope of removing the material or symbolic traces of previous use including physical pollution and ill fortune as well the memory of the previous owner, and thus making the purchased object (piece of clothing, family house, etc.) cease to be a part of the previous owner's "extended self." The symbolic emptying - the partial or complete erasure of the meanings and values associated with the purchased piece-enables the new owners to substitute their own preferred meanings and values for the previous ones. Thanks to this process-and to the modification of material properties such as mending faults and decorating surfaces-the second-hand object can be repersonalized and will become part of the new owner's "extended self." In the words of Gregson and Crewe (2003:144), for several second-hand goods, the "problem is...that there is too much trace of previous ownership, traces that need to be expunged, removed."

One of the earliest analyses focusing on the significance of the symbolic divestment practices 
related to second-hand goods is McCracken's (1986) work, which argues that consumers resort to their use in two cases. In the first mode, when consumers buy second-hand commodities they may attempt to "erase the meaning associated with the previous owner. The cleaning and redecorating of a newly purchased home, for instance, may be seen as an effort to remove the meaning created by the previous owner" (McCracken 1986:80). Secondly, consumers often use depersonalizing practices to remove meanings and emotional values before putting up for sale or withdrawing from use their own valued commodities regarded as a part of their "extended self." "In moments of candor, individuals suggest that they feel 'a little strange about someone else wearing my old coat"” (McCracken 1986:80). These practices, McCracken (1986:80) argues,

suggest a concern that the meaning of goods can be transferred, obscured, confused, or even lost when goods change hands (Douglas 1966). Therefore, goods must be emptied of meaning before being passed along and cleared of meaning when taken on.

Gregson and Crewe (2003; see also Lastovicka and Fernandez 2005) also devote considerable attention to the consumer rituals aimed at removing meanings and emotional value from goods, which their interlocutors employed primarily in the case of second-hand goods purchased at charity shops. The most common of these rituals are careful washing and dry cleaning. They argue that cleansing rituals or practices are tools

by which the bodily presence of the unknown previous owner/s is erased; the means through which the taboos of wearing other people's clothes are countered; and...a means of personalizing...The rituals of cleansing purchases, then, are practices of erasure and reincorporation. [Gregson and Crewe 2003:163]

\section{The Symbolic Patina of Second-hand Commodities-the Ownership History-as a Source of Value}

For several second-hand commodities, however, the fact that someone else has possessed them before leads to no decrease in value-on the contrary: it can constitute added economic value and the basis of their social and market desirability. These commodities are therefore attractive primarily because of their cultural biography and, within that, their ownership history or, more precisely, because "they retain a part of the extended self of valued others" (Belk 1988:149).

This is exactly the case with family heirlooms, various objects previously owned by celebrities (film stars, musicians, etc.) or other famous people (monarchs, politicians, scientists, athletes, etc.; Giloi 2011; Newman et al. 2011), and identity symbols conquered from a rival social group (Harrison 1995, 1999). These goods primarily owe their distinguished emotional and economic value to their ownership history and the symbolic interactions taking place between the new owner and the ownership history (or, more accurately, the previous owners integrated into it).

When we find second-hand objects attractive because of their previous owners, we in fact try to identify with them; a frequent aim of "owning artifacts that once belonged to a famous historical 
figure" is "to gain the glory of the superstar" (Belk 1988:149). Gregson and Crewe (2003:146) similarly argue that second-hand commodities "are particularly meaningful, and take on an almost sacred character through, for example, contagious contact with famous and/or imaginary others (rock stars, film stars, designers)." Newman et al. (2011:216) note that the patina-oriented consumption associated with second-hand goods may be inspired by two further motivations in addition to the positive meanings associated with the previous owners. One of these has to do with the ever growing and increasingly globalized market of the personal belongings of celebrities and other famous people, i.e., with the belief held by many that purchasing these objects is a profitable investment and after a period of time they can be sold at a price higher than the purchase price. The third motivation is rooted in the fact of physical contact with the previous celebrity owner, namely, the assumption that "a person's immaterial qualities or essence can be transferred to an object through physical contact" (Newman et al. 2011:216). Newman et al. argue that the interrelationship between these three motivations is often difficult to define, and also note that in some cases there may be considerable market demand for second-hand objects owned by celebrities with a negative social evaluation (criminals, etc.).

The situation is similar with possession of family heirlooms or memorabilia: their emotional and identity value for the current owner comes from a sense of having contact and being able to identify with their predecessors. Objects passed down from generation to generation in effect largely owe their central role in the construction and materialization of the family or paternal history and identity to their ownership history.

Second-hand commodities acquired through patina-oriented consumption are therefore desirable and attractive primarily due to their biographic value (Hoskins 1998; 2006) deriving from the fame and social prestige or descent of the previous owners associated with them. In their case, ownership history is a positive symbolic property and therefore an intense "proprietary contest" (Harrison 1995) often evolves between potential buyers to purchase these second-hand goods and become integrated into their ownership history. ${ }^{1}$ I shall use the term patina-oriented consumption for the type of consumption where ownership history-regarded as a highly estimated symbolic patina-is a decisive value-increasing and desire-creating property of the commodity, which mostly explains why the market price of the piece in question exceeds its original purchase price.

The social and economic significance of ownership history is shown precisely by the fact that several patina-seeking consumers make a significant effort to carefully reconstruct, display, and advertise the cultural biography of the second-hand goods they purchase. Gregson and Crewe (2003:144) use the term "recovery rituals" to refer to the group of practices by which "the former meanings and traces of ownership are retrieved, recaptured and reimagined" by the present owners of second-hand commodities.

While earlier use and ownership history may decrease the value of many second-hand commodities, motivating sellers to try to hide this from the buyer (fashion-or novelty-oriented consumption), for other second-hand goods - the objects of celebrities or Gabor Roma prestige items - ownership history is an important value-, desire-, and price-increasing property that sellers spotlight and emphasize (patina-seeking consumption). In the course of fashion- or 
novelty-oriented consumption, the market value of second-hand commodities is generally lower than the original purchase price. In patina-seeking consumption - due to the biographic value and singularization (Kopytoff 1986) coming from ownership history, and the interplay between the former possessors' prestige or fame and the present owners' social reputation-second-hand commodities often change hands for several times more than the original purchase price.

In the paragraphs above I argued that previous use and the resulting ownership history may constitute a value-decreasing factor for some second-hand goods, and sellers therefore attempt to make this history invisible (novelty or fashion-oriented consumption). In several other cases, in contrast, such as for the personal belongings of celebrities, ownership history is an important value-, desire-, and price-increasing property that sellers and collectors spotlight and emphasize (patina-oriented consumption). While the market price of second-hand goods whose value is determined by a fashion-oriented consumer attitude tends to be lower than their original purchase price, in patina-oriented consumption, second-hand goods often change hands for several times their original purchase price due to their biographic value deriving from their ownership history and to the possibility of a symbolic interaction between the former possessors' prestige or fame and the present owners' social reputation. ${ }^{2}$

\section{Background: The Romanian Gabor Roma and their Politics of Difference}

The Gabor Roma (see Figures 1-4) are one of the Roma populations living in Central Romania. ${ }^{3}$ Most Gabors belong to the Seventh Day Adventist Church.

The dominant subsistence strategy among them is intermediary trade (bižnico). Most of the Gabor merchants trade in Romania and Hungary. Since the millennium, several of them have done business in Croatia, Serbia, and Slovenia, and later in Slovakia and Austria. In the last few years, some Gabor traders have also tried their luck in other countries, including France, Poland, Germany, Belgium, the Netherlands, Albania, Macedonia, and Greece. In 2010 and 2011, Russia also become a popular commercial destination for many merchants.

Among the possible forms of intermediate trade in Romania, they favor peddling, selling at second-hand markets, and selling on to retailers goods imported in bulk from abroad. Their clients generally come from less mobile buyers with an average or low standard of living, for the most part living in small settlements, as well as customers visiting second-hand markets. What makes dealing with the Gabors attractive is principally the lower than average price, the possibility of bargaining, and, in the case of small settlements, the "home delivery" of goods that are otherwise difficult to obtain.

In Romania-especially in the regions where the supply of goods is weaker-the most extensively traded articles are second-hand shoes and clothing (leather coats, jeans, jackets, shirts, work clothing, etc.). The traders who sell in markets here also often stock new clothing articles (trousers, socks, underwear, etc.), carpets and curtains generally imported from Turkey, blankets, sets of pans and cutlery, used and new mobile phones, and antiques (old clocks and 
Museum Anthropology Review 9(1-2) Spring-Fall 2015

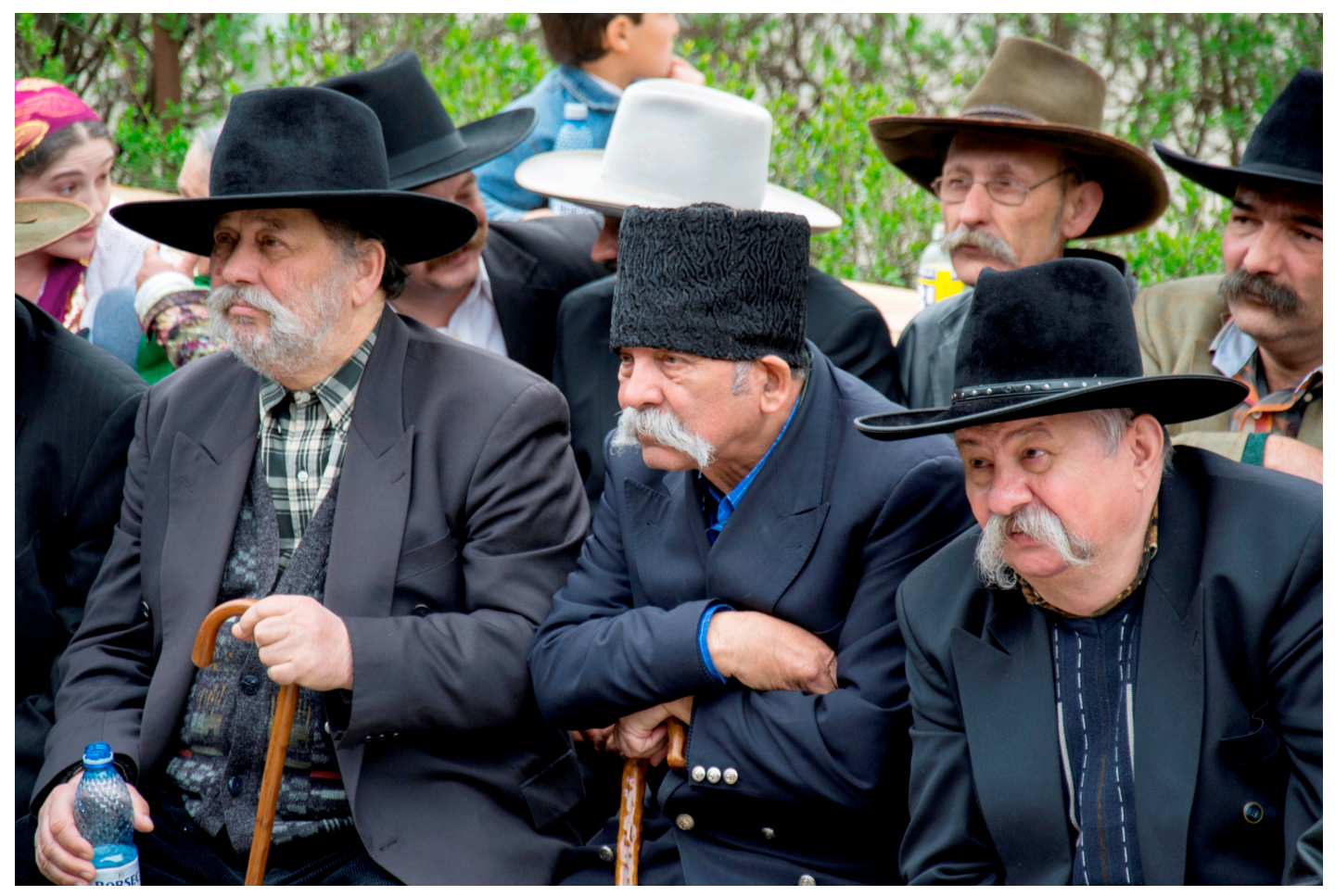

Figure 1. Gabor Roma men at a funeral. Photo by the author, 2014.

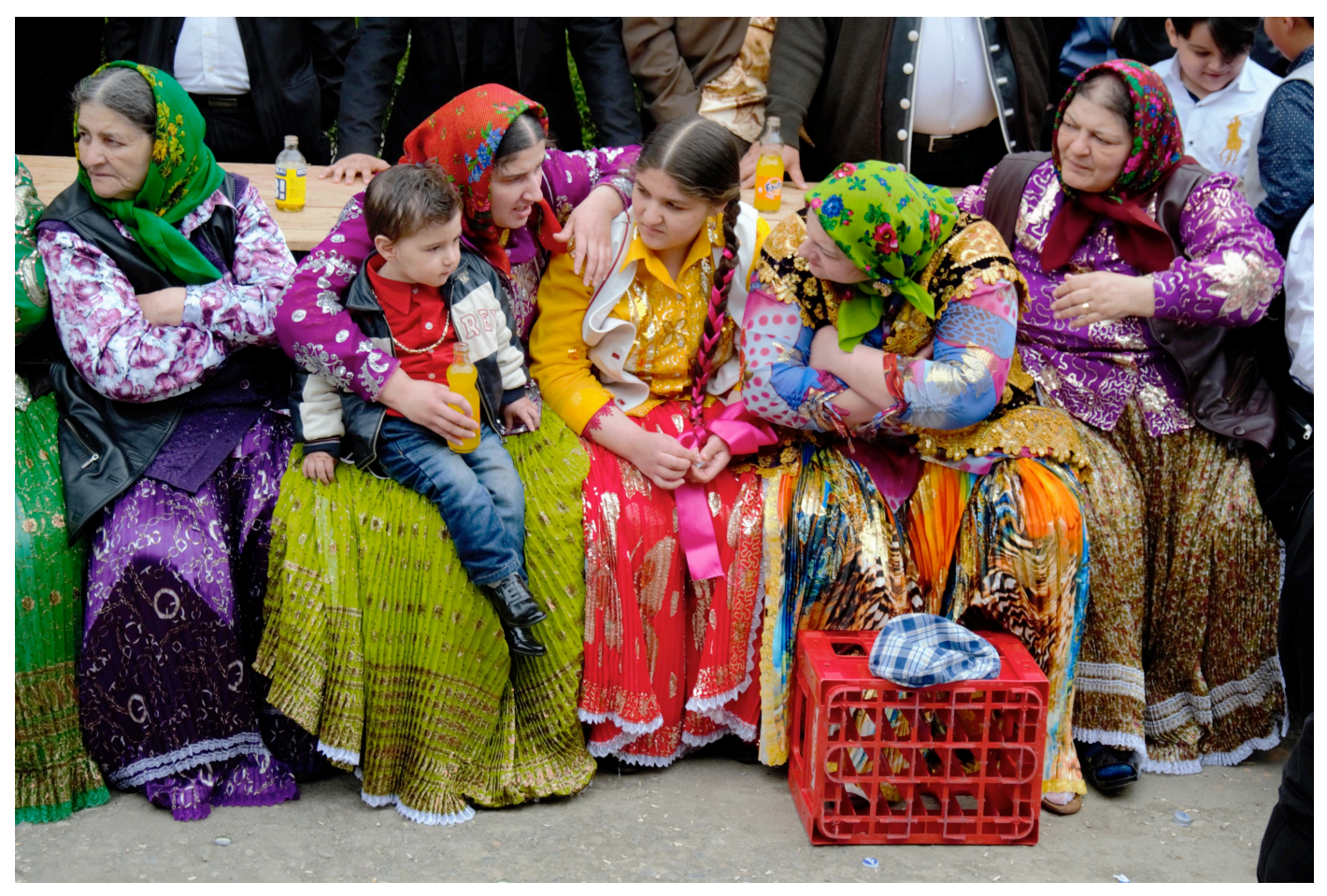

Figure 2. Gabor Roma women at a funeral. Photo by the author, 2014. 
watches, mortars, paintings of lower value, etc.).

Making copper objects, once one of the major sources of income, gradually declined in the period before the change of political system in 1989 and has now almost completely lost its former economic significance. Now only a few older men still have the skills and in their spare time make brandy stills, kettles for jam-making, and other copper objects intended as "curiosities" for market sale or as gifts for non-Roma in return for favors (for help given in medical care or in handling official affairs, etc.).

The Gabors making a living as tinsmiths mainly make gutters and downpipes (for houses, as well as for industrial facilities, churches or schools), they roof buildings with tin sheets, make handmade roof ornaments to meet individual requirements, buckets, watering cans, funnels and other kitchen and garden implements. Some of them are craftsmen who make street litter bins and, with the help of Gabor Roma skilled in welding, also large containers that can be lifted onto trucks for the transport of raw materials and rubbish. Others, with the help of subcontractors, undertake the construction of whole buildings (houses, industrial facilities, etc.). Many Gabor

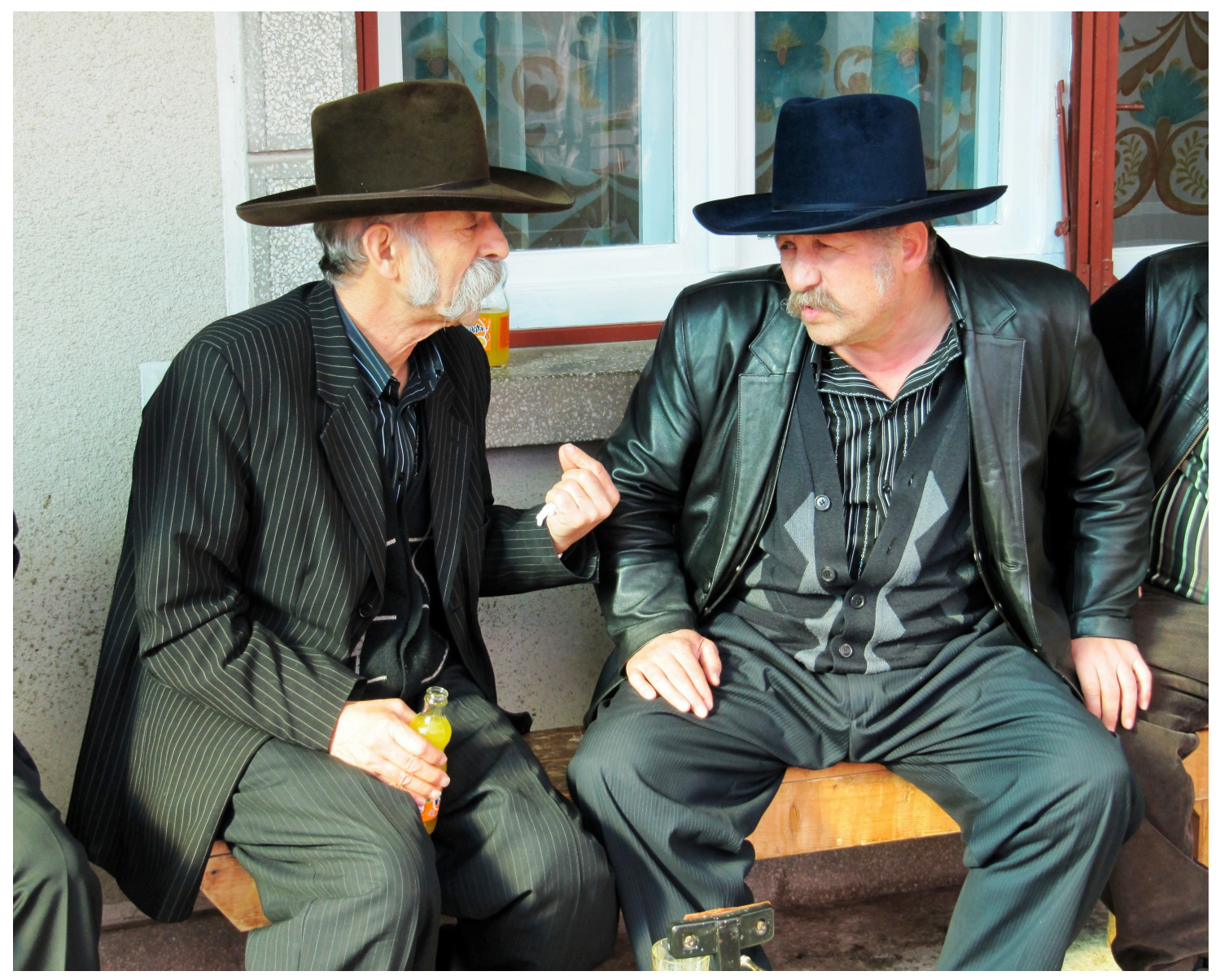

Figure 3. Political discourse among Gabor Roma at a funeral. Photo by the author, 2010. 


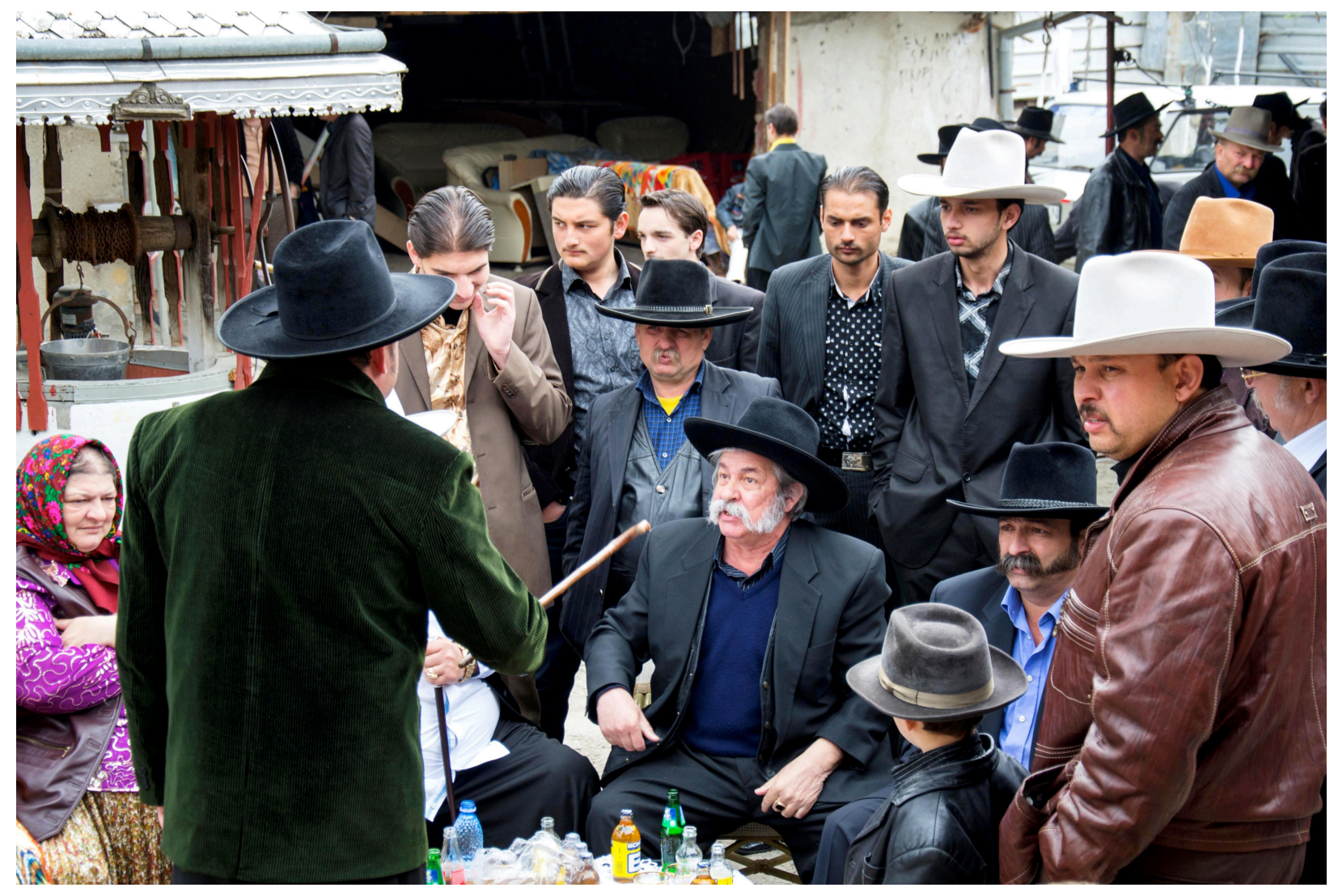

Figure 4. Political discourse among Gabor Roma at a funeral. Photo by the author, 2014.

Roma who make their livings as tinsmiths also regularly participate in local and regional public procurement tenders.

The Romani politics (Roma politics; Ŕomani politika) characteristic of the Gabor Roma is a "tournament of value" (Appadurai 1986:21) serving for the construction, representation and manipulation of social and economic differences. It includes a series of partly ethnicized symbolic arenas, practices, and ideologies. The Gabors define the prestige relations and vertical social distance or closeness between individuals, families, patrilines, and local communities primarily on the basis of the results achieved in the symbolic arenas of Romani politics. These arenas are as follows: (1) the accumulation of economic capital, with special regard to success achieved in the prestige-object economy (see below); (2) the politics of kinship I: the position occupied in the local, regional, and ethnic group prestige hierarchy of Gabor Roma patrilines; and (3) the politics of kinship II: the accumulation of relational capital among the Gabors. They attribute special significance to two types of relational capital: first, to xanamikimo (marital alliance) to be established with influential Gabor men through arranged marriages (politics of marriage) $;{ }^{4}$ and second, to the social network primarily composed of patrilineal male relatives (brothers, sons, male grandsons, etc.) and co-fathers-in-law, which can be mobilized if needed. ${ }^{5}$ The fourth (4) symbolic arena is connected to the Gabor Roma concepts of phirajimo (behavior) and patjiv (honour, respectability, social esteem), where the individuals, families, and patrilines 
compete with each other for the establishment, display, and preservation of their positive public image. In the construction of this image, an individual's behavior is primarily taken into account - more precisely, his or her relationship to the Gabor Roma ethics of managing social relations and interactions.

Romani politics is not part of Romanian national or regional party politics: it is not associated with political organizations or the activity of county or local governments or linked to the state institutions and the positions that can be held there. Nor is it associated with the various forms of Roma self-organization and interest representation: it is separate from the activity of the Romanian civil organizations dealing with protection of the rights of Roma, from the efforts at Roma nation-building, and from the question of the parliamentary representation of Romanian ethnic minorities. In other words, Romani politics is an ethnicized and relatively closed informal sub-system of politics of difference, largely "invisible" and unknown to the members of the Romanian majority society.

Those participating in Romani politics do not compete for positions endowed with formal political power, but for the accumulation of social prestige and renown, as well as the honorific titles interpreted as symbolic trophies that are reserved for those most successful in Romani politics (see Figures 3 and 4). These honorific titles are čaladvezetăvo (family leader), baro rom (great-Gabor Roma - man) and bulibaś or faluvezetăvo (village leader). The latter is reserved for well-respected and extremely influential men who are the most successful in Romani politics in their respective local community. The honorific title of bulibaś or faluvezetăvo is used only in some Gabor communities-in settlements where only a few Gabor families live, which typically belong to the same patriline, these honorific titles are not in use. Similarly, the title of baro rom was used to refer to only a few persons by my interlocutors. The significance of bulibaś or faluvezetăvo is often illustrated by such expressions as, "he is the Gabor Roma man who leads the village," or "he is the sole [the base] of the village."

None of these honorific titles entitles the possessor to give commands "in others' courtyard" or to dispose over the goods of other families. To quote one of my interlocutors,

a stranger [non-family member] has no right to command, because here everyone commands to himself. Do you understand? The only thing is that all Roma speak about the Gabor Roma man who has a title like this [who is honoured as bulibaś or baro rom]. [Communication to the author July 21, 2006]

The bulibaś or baro rom can count on only one type of social capital, the reputation and prestige coming from their individual success in Romani politics, when they want to enforce their will or effectively represent their own interests. That is, if they want to act in accordance with the Gabor Roma ethics of sociability, they can affect (non-family) social and economic processes and relations through indirect forms of pressure, such as persuasion (see also Szalai 2014).

While there is no substantial obstacle preventing Gabor men from joining national or regional party politics, the active participation of non-Roma in Romani politics is essentially inconceivable. Above all because most of the symbolic arenas of Romani politics are organized 


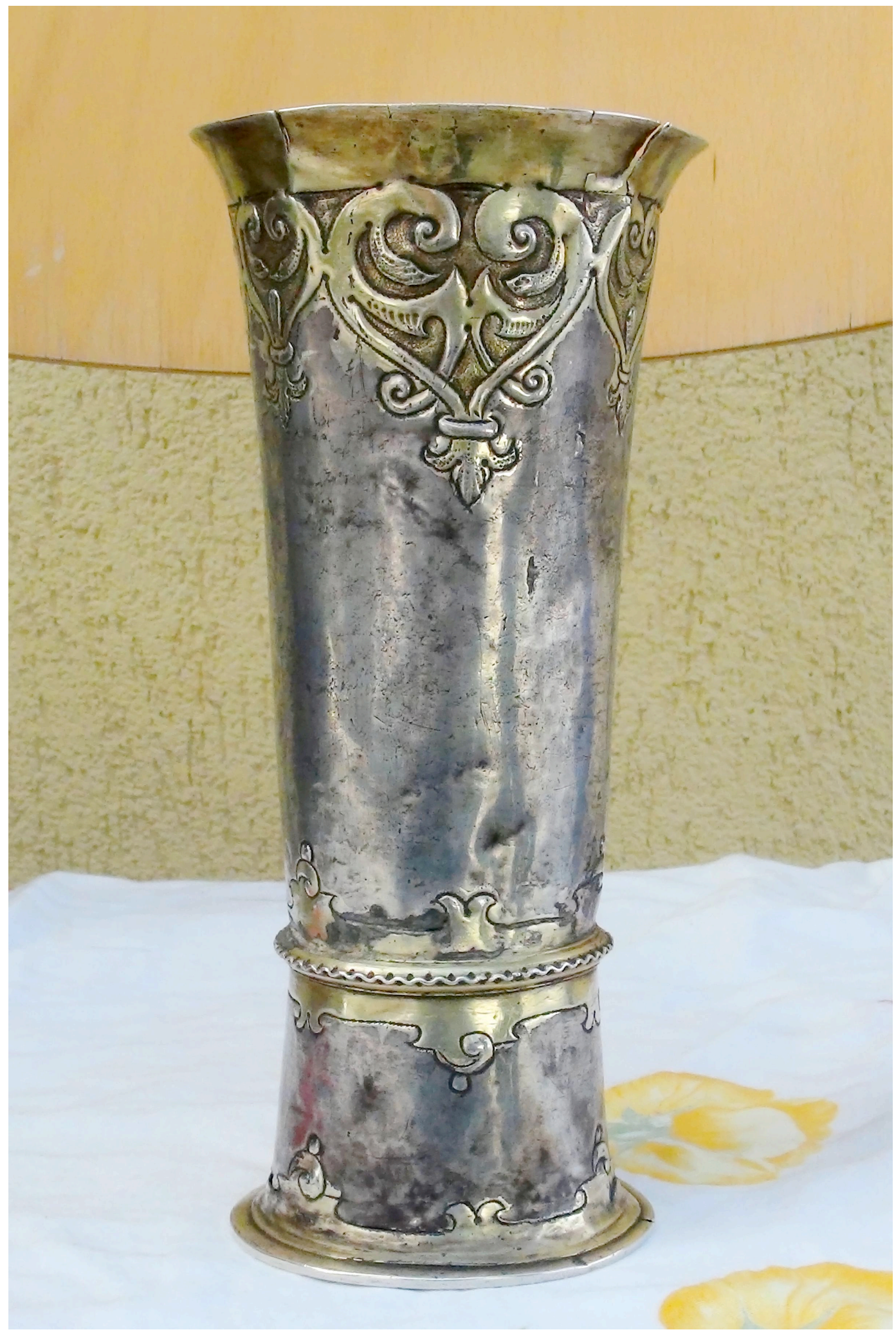

Figure 5. A Gabor Roma beaker. Photo by the author, 2014. 


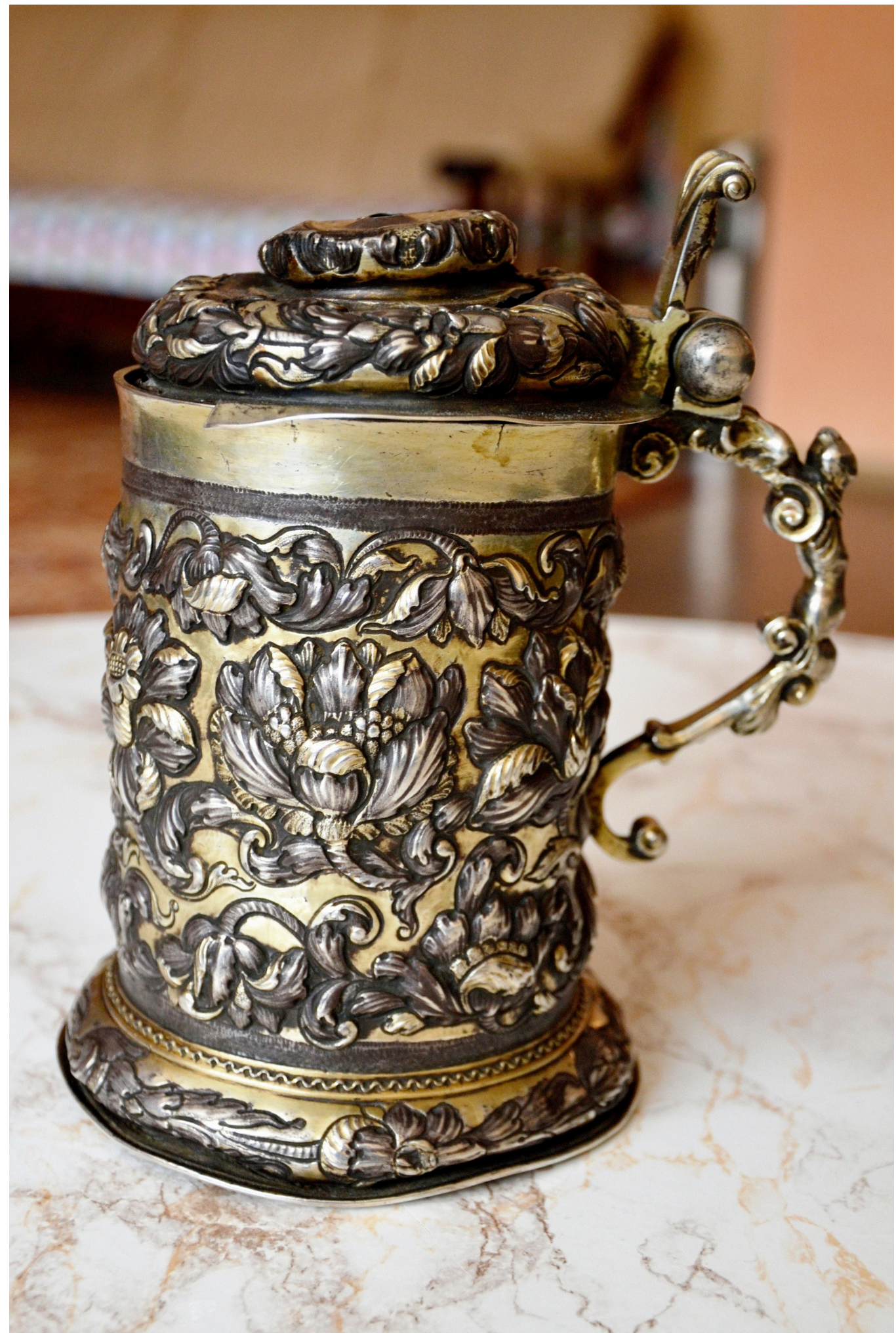

Figure 6. A Gabor Roma tankard. Photo by the author, 2011. 
around ethnicized goods, and on the basis of ethnicized ideologies of value, that is, they are closely linked to the ethnic identity and history of the Gabor Roma. As a consequence, with the exception of a few anthropologists and antique dealers, these symbolic arenas of Romani politics are of interest only to the Gabors. The successes that can be achieved here (purchase of a prestige object, a marital alliance formed with an influential Gabor man, etc.) and the fame they bring cannot be converted to social respect or prestige in the non-Roma world (for example, in Romanian party politics).

Over the course of the last 150 years, the Gabor Roma have developed a prestige economy based on taxta (silver beakers /taxtaj - singular/, see Figure 5) and kăni (silver roofed tankards /kanasingular/, see Figure 6). The prestige economy under discussion is an informal, translocal, ethnicized, and gendered segment of the Romanian economy, and a significant part of the Romani politics characteristic of the Gabor Roma. These objects, produced by non-Roma silversmiths - mainly Transylvanian Saxons and Hungarians-were originally owned by nonRoma aristocrats, burghers, guilds, and Calvinist Church congregations.

When the Gabor Roma assess the value, or negotiate the price of these pieces, no value is given to their non-Roma silversmiths or previous non-Roma possessors. Instead, only previous owners from their own Roma population are regarded as a potential source of added value. The renown and prestige of a beaker or tankard's earlier Gabor Roma owners (symbolic-mnemonic patina), along with the item's material features, constitute the most important qualities Gabor Roma buyers consider and pay for when making a transaction. The estimated value attributed to material characteristics is calculated on the basis of partially ethnicized prestige object aesthetics developed by the Gabors (material patina). The pieces are singularized: each of them is characterized by a proper name, a unique composition of material properties, and an individual biography. Consequently, the Gabors' prestige economy is highly ethnicized. In the transactions occurring among them, buyers purchase silver objects intertwined with their own ethnic past, identity, and prestige object aesthetics.

Gabor Roma regard the more valuable prestige object as pieces loaded with Romani political meaning and significance; they define them as political trophies. As possessing them can be a source of significant renown and prestige, their owners try to retain the more valuable objects as long as possible and to bequeath them to their sons. Hence, there is often an intense rivalry between potential buyers. Those who own these pieces sell them only if faced with economic crisis. Furthermore, prestige objects play a significant role in the construction and materialization of ethnic and patrilineal identity, history, and economic success.

Today, the Romanian Gabor Roma possess numerous beakers and tankards. The members of the Gabor community where I conducted most of my fieldwork, for example, own more than three dozen of such objects. These pieces can only be found in families that possess both the political ambition and the economic resources necessary to obtain them. The two most important resources are cash wealth, and the inheritance of a prestige item.

Silver beakers and tankards - regarded as symbols of economic prosperity-constitute the most expensive category of consumer goods for the Gabor Roma. While the price of these objects 
usually does not exceed $\$ 9,000-11,000$ on the European antiques market, among the Gabor Roma, the more valuable pieces may sell for several times as much: $\$ 200,000-400,000$. The highest purchase price in the deals I documented- $\$ 1,200,000$ - was paid in September 2009 by a wealthy and influential Gabor man for a highly appreciated beaker that had been in pawn for a number of years at a Gabor creditor.

\section{Recreating and Materializing Social Differences through Patina-oriented Consumption: The Post-socialist Ownership History of a Second-hand, Luxury Commodity (2000-2007)}

\section{Value Aspects}

The object in question is a seven decilitre, richly gilded, trumpet-shaped, footed silver beaker. It is decorated with a series of elaborated floral motifs, the richness of which was characterized by one of my interlocutors in the following way: the surface of this object "is so richly decorated that there is no place on it where one could put down a needle." (That is, there is no unadorned part of the surface that is larger than a needle.)

In addition to its attractive material properties, this beaker is also considered a valuable object because of its Gabor Roma social career. In the words of one of the influential Gabor men's son, who often participated in prestige-object transactions as a broker, the piece in question is

old! An antique! It used to belong to our predecessors [the Gabor Roma], it's our heritage from our predecessors! It belonged to important people, famous Roma! It's the coat of arms [the fame from the social prestige of the former Gabor owners], the coat of arms that costs, not the material...A gilded silver beaker...that's where our wealth is. [Communication to the author June 16, 2006]

A number of successful, influential and widely known people are in its biography among the eight recorded Gabor owners. The fame arising from its ownership history is due primarily to the second and fourth owners whose wealth and social prestige contributed significantly to making this object especially valuable in the eyes of the Gabor Roma. (Most of my interlocutors were of the opinion that the piece was somewhere in the middle of the ranking of the ten most valuable Gabor beakers.) Its first known Gabor owner (first owner) sold this beaker in the 1930s to the head of a Gabor family living in one of the small settlements in Mures County who, up to his death during the Second World War, acquired an especially valuable "collection" of prestige objects: he owned seven silver objects (second owner). Because his three sons were still minors at the time of his death, the objects passed into the care of his widow (third owner) who was plagued with constant financial difficulties and eventually sold all seven objects. Four of those objects - three beakers and a tankard - are still possessed by Gabor Roma, while the remaining three were purchased by Cărhar Roma buyers. ${ }^{6}$

In the mid-1950s the widow was obliged to pawn the beaker examined here to a Gabor Roma 
creditor, also from Mures County. During the seven years of the loan, the total sum owed-including the capital and the interest-was more than 55,000 old Romanian lei. ${ }^{7}$ In the seventh year the creditor-whose principal aim was to acquire the ownership of the beakerclaimed that he was in urgent need of cash and forced the widow to make a decision: either to pay off her debt or sell the object to him so that he could then sell it himself. (He did not seriously intend to sell it, he made this statement only in order to disguise his real aim, namely to purchase the beaker.) But the creditor did not succeed because, although the widow decided to sell the beaker, she sold it not to him but to a respected and wealthy Gabor man in Cluj County in 1961 for 105,000 old Romanian lei (fourth owner). ${ }^{8}$ After the death of the Cluj County owner in the mid-1970s the beaker became the property of his eldest son (fifth owner) who- to settle his debts-sold it in 1982 to one of his sons-in-law for 1,700,000 old Romanian lei ${ }^{9}$ (sixth owner; "Janko" ${ }^{10}$ ). For close to two decades, Janko retained full possession of the beaker but in 1998 he was sentenced to two years of imprisonment for smuggling. In his absence, his family accumulated considerable debt by sending him money regularly and taking out loans to make up for the loss of his earnings.

\section{Mate-The Seventh Owner: Mate Buys the Beaker}

Shortly after his release in November 2000, Janko, faced with the creditors' impatience, decided to sell his beaker and settle his debts from the proceeds. He called a prestigious Gabor man living in Mureş County named Kalo who had experience in prestige-object brokerage, and asked him to sell his beaker in order to settle his debts.

Kalo, who also had a silver beaker bequeathed by his father, did not acquire his wealth as a trader or a building contractor as the majority of Gabor men usually do, but as a manager of Gabor Roma social and economic relations. A remarkable part of Kalo's income came from the following sources: (1) wages and success fees received for his participation in the organization of marital alliances as well as for his activity as a prestige-object broker, (2) marriage payments and other cash gifts received in the course of marrying off his own grandchildren, and (3) investing some of his income in lending money for interest.

Kalo thus hurried, together with his two sons, to Janko's Cluj Napoca home, expecting to acquire a significant success fee from the deal. Having accepted the commission, Kalo made a formal request to see Janko's beaker to check its nominal authenticity, that is, to verify that it was truly identical with the piece known by the Gabor Roma as Janko's beaker. Then he inquired about the amount of Janko's debt as well as the price he expected to receive for his beaker, and Kalo himself estimated its value. Finally, they agreed on the amount of the success fee due to the broker: 20,000 German marks $(\$ 9,063)$. In the terms of their agreement, this amount was independent of the final purchase price.

Kalo then visited some of his Gabor Roma acquaintances in Mureş County who he thought had both the political ambitions and cash reserves to buy Janko's beaker. Although the beaker was regarded as one of the ten most valuable Gabor prestige objects, none of the men Kalo visited wanted to participate in the deal. Their reason was obvious: none of them dared to do business 
with a seller of bad moral reputation. Most of them feared that Janko would ask additional sums, beyond the purchase price, after the sale, and that he would not shrink back even from conflict to achieve his aim. One of the main reasons why Janko commissioned a widely respected and influential broker was because he had correctly presumed that a number of Roma would be unwilling to do business directly with him. The broker's presence thus served-among others-to reduce distrust stemming from Janko's bad moral reputation and was interpreted as a guarantee of the deal's fairness.

After some unsuccessful attempts in Mureş County, the broker went to a hitherto overlooked acquaintance of his, Mate, from Cluj County. Mate, who enjoyed a lower social prestige, did not possess prestige objects. He had acquired most of his wealth after the change of the political regime in 1989, mostly through commissions received from state-owned construction companies, and had made some efforts to convert his economic capital into personal fame in the prestigeobject economy and in the competition for marital alliances with Gabor families with high social status. Like most Roma, Mate regarded success achieved in these symbolic arenas as a popular and effective means of accumulating political capital, re-conceptualizing prestige hierarchies and catalyzing upward social mobility. As "Mate was very eager to buy a good beaker," he was willing to risk potential conflicts with the seller.

According to his own recollections, the broker described to Mate the value and social significance of the beaker in the following manner:

It is an important and famous piece which is worth buying!...It is a richly decorated and gilded footed beaker, a very valuable object! It has great fame, because it belonged to the great $X$ [the second owner of the beaker] who lived in the village of Y. So you don't have to be afraid to spend your money on it...It is a beaker that will bring great renown to you. You can mention it and boast with it everywhere among the Gabor Roma! [Communication to the author August 14, 2003]

Mate, who was not experienced in estimating the value of prestige objects, completely trusted the broker. To quote Mate: "I will pay as much as you say for it, Kalo, if you say it is valuable and worth being purchased, then I will buy it!" Mate promised Kalo German mark 20,000 $(\$ 9,063)$ as a success fee if "he would stand on his side" and help him to purchase the beaker at a reasonable price.

After Kalo negotiated with both parties separately, he organized a meeting for them at Janko's home. Here, in November of 2000, after a brief bargaining session, they agreed to a purchase price of German mark 300,000 $(\$ 135,954) .{ }^{11}$ Mate, however, did not have enough cash at his disposal and needed to borrow more than German mark 100,000 $(\$ 45,318)$. He paid for the beaker in early December in the presence of the broker and his sons, as well as some close family members of both parties.

In addition to the purchase of this beaker, Mate also wanted to increase his renown in the politics of marriage. Therefore, in 2002, he arranged a marriage for his granddaughter with the grandson of Marko, a Gabor man who was extremely influential and widely honoured in his Roma 
population. Marko possessed two outstandingly valuable prestige objects-a beaker and a roofed tankard-but his own contribution to the fame of his paternal line was rather modest, primarily because he was a man of "poor income." He tried to attenuate his continual financial difficulties-debts—by, among other things, commodifying the fame of his patriline (especially his father and grandfather). This involved asking for high marriage payments when marrying his children and grandchildren, and accepting cash gifts of great value from aspiring and wealthy Gabor men of low social prestige for a promise of marital alliance.

They agreed that as soon as their grandchildren reached the necessary age (Marko's grandson was one and a half, and Mate's granddaughter was four years old at that time), they would marry and create a marriage alliance between themselves. A lengthy bargaining began regarding the marriage payment Mate would pay Marko. Marko referred to his and his family's prestige and the outstanding value of his prestige objects (a beaker and a tankard). He first asked Mate for $\$ 80,000$, but in the end they agreed on $\$ 60,000$ dollars to be paid in two instalments: half on the occasion of the engagement and half at the wedding of their grandchildren.

The engagement was held on March 19, 2002, in a restaurant in Mate's town in Cluj County. In accordance with the gendered patterns of space usage characteristic of public events among the Gabor Roma, the men and the women sat at separate tables. After several hours of Romani political discourse between the invited Gabor men, they ate, and Mate publicly counted half $(\$ 30,000)$ of the marriage payment he promised Marko on the table. Mate then publicly shared mita, a type of cash gifts interpreted as an "expression of joy", from himself and Marko, among the Gabor men present. ${ }^{12}$ (The broker who coordinated the marital alliance privately received $\$ 5,000$ from each party.)

\section{Mate Puts his Beaker in Pawn}

Mate, however, did not enjoy his increased renown for long. Indeed, from the beginning of the autumn of 2002 onwards, he fell further into debt, and by the winter of 2003-2004, he was forced to put his beaker in pawn for a significant loan-almost $\$ 100,000$ - with a Gabor man living in one of the Romanian cities next to the Hungarian border. Despite periodically sending small amounts of money to the lender to pay off at least part of the interest, by the end of 2005 it became clear to Mate that he would never redeem his beaker, and he hurried to find a buyer for it.

\section{The Prospective Buyer: Laji-The Eighth Owner}

One of the buyers interested in Mate's beaker was Laji, a 36-year-old Gabor man of modest social prestige living in Cluj County. He had acquired considerable wealth as a merchant, but had not inherited or bought any prestige objects. Laji and his father, like Mate, had strong Romani political ambitions and placed great emphasis on converting part of their disposable income into a marital alliance, into a valuable prestige item to significantly increase their renown, or into both. 
As one of Laji's daughters had reached the age considered ideal for marriage, Laji and his father took stock of the Gabor Roma families with a son of similar age in order to find an influential cofather-in-law with considerable success in Romani politics. Laji, due to the modest social prestige of his family, was only attractive as a co-father-in-law for an influential Roma because of the high marriage payment he could offer with his daughter.

Laji established a marital alliance with the son of an extremely influential Gabor man in his sixties, living in Mureş County. The father of his co-father-in-law (hereinafter: old co-father-inlaw $^{13}$ ) was known in his own, local, Gabor Roma community as a village leader. He was also one of the most influential brokers who regularly took part in the management of the prestige-object transactions between the Gabors, and between the Gabor and Cărhar Roma. Furthermore, the "old co-father-in-law" had five sons and four brothers, which constituted a significant relational capital.

Laji gave his new co-father-in-law (the third son of the old co-father-in-law) $\$ 100,000$ as a marriage payment during the wedding in the winter of 2002-2003. ${ }^{14}$ In the course of the wedding and afterwards, Laji distributed more than $\$ 30,000$ as cash gifts among his relatives, friends and acquaintances. $\$ 10,000$ was given in secret to his "old co-father-in-law" as thanks for supporting the marriage of the young couple and the marital alliance between the families.

\section{The Price Bargaining}

In the winter of 2005-2006, everyone suspected that Mate's beaker would soon be sold. This started among the Gabor Roma who would be able to raise the money necessary to buy it, and within this circle, the men who would have the necessary political ambitions (who wanted to "put their money in a beaker"). Over time, the group of competing potential buyers narrowed down to two Gabor men.

Laji was among these and in late 2005, after a number of phone calls, he went to Mate with his father to agree on the purchase price. Mate, however, asked an unrealistically high amount for the beaker- $\$ 800,000$ and later $\$ 500,000$ - that Laji did not want to pay. Yet, a month later, Mate, pressured by his impatient creditors, called Laji to continue the price bargaining. Mate said that they could continue on the condition that no one else attend the bargaining except Laji, his father, and one of his uncles on his father's side, and that these people should contact him in secret in Mureş County where he was hiding from his creditors.

According to his recollection, Laji's uncle, who participated in the transaction as a broker, warned Laji's father as they were approaching Mate's hiding place, "the beaker is worth three [\$300,000]. I'm telling you so you know. But you and your son must give fifty $[\$ 50,000]$ or a hundred [\$100,000] more to purchase it: Mate doesn't want to sell it to you because you're on bad terms, since you loved his wife."15

Mate-referring to the shame he had had to endure back then-opened the negotiations by again asking for $\$ 500,000$, which Laji and his father said was too much and named their last offer as 
$\$ 400,000$. Finally Mate agreed to the $\$ 400,000$ because Laji's uncle, an effective broker, warned Mate that no Gabor Roma would offer more than this for the beaker and that the pressure of his creditors would leave him no time to wait for another serious buyer. In the words of Laji's uncle to Mate,

You know, if you have any sense, forget the love [reference to the former love affair between Mate's wife and Laji's father] now when your life's on the line [reference to the impatient lenders and the threats coming from them]. The love of your wife. You already got $\$ 100,000$ extra from us [as I have mentioned, Laji's uncle estimated the beaker to be worth $\$ 300,000]$. You have no reason to be angry, not for the rest of your life!! Bring me water [a soft drink] and a brandy because I, $\mathrm{X}$ [he mentions his own first name], have made you this hundred thousand [i.e., he convinced Laji and his father that they should pay $\$ 100,000$ more than the estimated value of the beaker]!! [Communication to the author August 4, 2008]

Laji's family had to face another challenge apart from the collection of the purchase price. Laji had to ensure that his old co-father-in-law, considered one of the most experienced prestigeobject brokers among the Gabors, would not be insulted by the fact that he was not allowed to participate in the bargaining. To avoid publicly humiliating the old co-father-in-law and later conflicts, Laji and his relatives immediately went to him and told him the details of the bargaining. When the old co-father-in-law heard about the negotiation he angrily said to Laji: "Did you make a fair [transaction]? You snotty!...without me?!" (communication to the author September 4, 2008). They promised him and his sons a significant cash gift as a kind of compensation. At the same time, they agreed that after paying the purchase price they would tell anyone curious about the details that the old co-father-in-law was present during the price bargaining, and that it was, in fact, primarily directed by him.

Laji's jubilation, however, did not last long. One of his political rivals found out about the impending beaker purchase and "pulled up" (provoked) Mate by referring to the secret love affair which developed in the 1980s between Mate's wife and Laji's father, and which ended with public shame and a severe conflict between the two families. The rival tried to "ruin the fair" by arguing that if Laji purchased the beaker, it would erect an "eternal monument" to Mate's wife's adultery and drag their shame back into the limelight. Mate's Romani political competitors would ironically mention that the same man's son purchased his beaker whom "loved away his wife." Thus, Mate - out of anger and fear of being shamed - terminated the oral contract he had established with Laji.

\section{The Emergence of a Rival Buyer and the Manipulation of Nominal Authenticity}

In early 2006, another ambitious Gabor Roma attempted to buy Mate's beaker. Tibor, who lived in Mureş County, began to negotiate with Mate and offered him $\$ 375,000$ for the beaker. Despite the fact that his offer was $\$ 25,000$ less than Laji's, due to the aggravated conflict with Laji's family, and to avoid the extra shame and verbal insults that could be expected if he sold the beaker just to Laji, Mate decided to sell it to Tibor. Tibor did not have enough cash to purchase 
Mate's beaker and hastily sold his own prestige item - a large and modestly ornamented footed beaker his father had purchased in 1985 for 700,000 old Romanian lei ${ }^{16}$ from a Gabor prestigeobject owner. The sale wasn't difficult for Tibor as a wealthy Cărhar Roma man in Sibiu County — for whom this object was especially attractive for its large capacity — had tried several times to acquire it. Tibor visited this Cărhar man and received $\$ 200,000^{17}$ for his beaker. He used this along with the money he had borrowed from several sources and the cash he had at his disposal to make a large down payment on the beaker. Furthermore, he planned to take over two of Mate's debts, worth more than $\$ 70,000$.

Finally, on May 29, 2006, Tibor went a Romanian city next to the Hungarian border to see the Gabor Roma creditor who had held Mate's beaker in pawn for two and a half years. Tibor carried more than $\$ 300,000$ with him, as well as Mate and a number of other Gabor men to act as witnesses. To his misfortune, Tibor also asked his father-in-law to assist him during the purchase. His father-in-law, considered a businessman "capable of everything," had accumulated a large debt and was not happy to hear about the prospective success of his son-in-law. He had entirely different plans with Tibor; since he knew that he would soon be forced to sell his own extremely valuable beaker, which he had inherited from his father, in order to pay off his debts. He wanted Tibor to buy or take this beaker in pawn from him, to "keep it in the family." Tibor, however, refused the request, fearing it was only Romani political "trickery." He suspected that if he took his father-in-law's beaker in pawn his father-in-law would exploit their age and status difference to "play a trick" and take it back before repaying the loan. Or, if he would buy it, his father-inlaw would continue to ask for more money years after the initial transaction by claiming that the beaker was sold below its real market value. His father-in-law also did not support the transaction out of envy and Romani political ambition; the father-in-law feared that their status distance would decrease significantly if Tibor bought Mate's beaker and he had to part with his own.

When they arrived in the city along the Hungarian border and were examining Mate's beaker, the father-in-law - much to Tibor's astonishment—-shouted at the creditor, feigning outrage: "don't blind me [do not try to deceive me]! Bring forth the other beaker! [Mate's real beaker.] That beaker is larger!" (communication to the author June 24, 2010). The creditor, however, consistently asserted that they were looking at Mate's beaker, and that he had not received any other beaker in pawn. Mate and several of the Gabor men accompanying Tibor also argued that this was the beaker Tibor wanted. To quote one of the witnesses- "it was not replaced and not copied [that is, the beaker they saw was not a less valuable piece nor was it a copy]" (communication to the author June 24, 2010). The doubt his father-in-law cast, however, was sufficient to make Tibor uncertain and "quit the fair" (to withdraw from the deal). As many of my interlocutors later pointed out, Tibor did not believe that his father-in-law could knowingly deceive him and cause him, his daughter, and grandsons such a great financial and symbolic loss by shutting down the transaction.

\section{Laji Pays the Purchase Price}

On the day Mate failed to make a transaction with Tibor, he called Laji and offered him the beaker. Laji seized the opportunity, and, on May 30, 2006, he travelled together with his family 
and a number of Gabor men supporting him to the city along the Hungarian border where Mate's creditor lived. (The leader of the almost fifty-member group was Laji's "old co-father-in-law" who previously complained because he could not be present at the bargaining between Laji and his father and Mate.)

Although Laji could have offered to pay only $\$ 375,000$, the amount Tibor had offered, he insisted on paying his initial offer price, $\$ 400,000 .{ }^{18}$ This decision was motivated, on the one hand, by his Romani political ambition. On the other hand, he was afraid that decreasing his offer, along with their earlier conflict (the adultery), would induce Mate to cancel the transaction. As one of the men who witnessed the transaction later formulated:

Mate would have preferred to sell it to Tibor for $\$ 300,000$, than to that one [Laji] for $\$ 500,000$. But the trouble was already hot to him [Mate]. He badly needed the money because he was in debt with other [non-Gabor] Roma [who did not shy away from menaces to enforce the repayment of their outstanding debts], so he had to pay the money back. [Communication to the author June 24, 2010]

Laji had only a few hours to prepare for the deal, but he succeeded to borrow a substantial amount of money to supplement the cash he had at his disposal. He brought the Euro equivalent of $\$ 250,000$ with him. (This was converted to U.S. dollars in the aforementioned city.)

Because of the failure of the negotiations on the previous day, Laji and his relatives placed special emphasis on verifying the nominal authenticity of the pawned object as a first step of the transaction at the creditor's house: they picked up the beaker a few times and thoroughly examined it before making the deal. The key figure in the examination was Laji's uncle who had led the secret negotiations with Mate and had previously had opportunities to put the object in hand and even drink from it as a young man. After checking its nominal authenticity, the uncle verified that the object presented by the creditor was without doubt the beaker that Mate owned, and Laji could safely buy it.

Mate's beaker had remained in pawn for nearly two and a half years. At the stipulation of the loan, Mate had received $\$ 90,000$ from the Gabor Roma creditor, and by May 2006, he had accumulated a total debt of $\$ 220,000$. Although Laji could have paid back Mate's entire loan, Mate would not allow it. In fact, the news of Tibor's unsuccessful transaction the previous day had rapidly spread among the Gabor Roma, so that by May 30, 2006, some of Mate's influential creditors had rushed to the city along the border and were impatiently waiting in front of the home of the creditor to get back at least part of their outstanding debts.

Therefore the parties made the following agreement. Laji provided $\$ 250,000$ to Mate, from which the latter gave $\$ 85,000$ as a partial repayment of his debt to the creditor holding his beaker in pawn. The remaining $\$ 165,000$ Mate distributed at his discretion between some of the most impatient and influential creditors present in the city. At the same time, Laji took over Mate's debt of $\$ 135,000$ with the creditor holding Mate's beaker in pawn on the condition that he would pay it within three months, at the latest. Additionally, Laji agreed to pay back one of Mate's, smaller $(\$ 15,000)$ debts. Thus, besides the $\$ 250,000$ paid on that day, Laji had to collect another 
$\$ 150,000$ to take possession of the desired prestige object; they agreed that the beaker would remain at the creditor until the full repayment of the debt.

Returning to his home in Cluj County, Laji tried to repay the loans he took for the beaker's purchase the previous day in order to pay the least amount of interest possible. Therefore, he put two houses he owned up for sale. One sold for 285,000 Euros and the other for 120,000 Euros.

Three months later, in August 2006, Laji returned to the creditor with several witnesses, gave him the agreed upon $\$ 135,000$, and received the beaker. He also paid back the other, smaller debt

during to ensure that the beaker became his both in terms of Roma and non-Roma law and business ethics.

\section{Sharing Mita}

In late August 2006, upon hearing the news of the beaker's purchase, several relatives, acquaintances, and friends came to see Laji and his father to share their joy, congratulate them on the transaction, express their good wishes, and take a look at the newly purchased prestige object. They also hoped to receive a mita (a cash gift defined as an "expression of joy"), as it is customary among the Gabor Roma in such cases. Laji, however, tried to dodge the moral expectation to give mita. He suspected that, due to his youth and his family's modest social prestige, the more influential Gabor men would be more encouraged to ask him for mita, and that many would not be satisfied with the amount he would willingly give them. His decision was motivated on the one hand by parsimony, and on the other by a desire to avoid conflict. Laji refused the requests to share mita and tried to cover his motivations by arguing that he had used all of his cash during the transaction, and was, in fact, in debt.

Laji planned to start the sharing of mita only months after the transaction, when public interest related to the purchase would somewhat decline and asking for mita would largely lose its timeliness - at least for those, who are not closely connected to Laji and his family. He planned to give a cash gift primarily to those who had offered him valuable assistance during the beaker's purchase.

In November 2006, more than two and a half months after taking the beaker into his possession, Laji gave mita-among the first ones-to his old co-father-in-law who had played a key role, along with his sons, in managing the transaction on May 30, 2006 (calming Mate's impatient creditors, etc.). It should be noted that the old co-father-in-law had already called Laji and his father in July 2006, warning them that they would owe him and his sons a total of $\$ 30,000$ mita if they gained definite ownership of the beaker - not least of all as "compensation for the shame" they caused him when they omitted him from the price bargaining. Laji and his father promised to visit him in September 2006 at the latest with his mita. Let us not forget that the great majority of Gabor Roma thought at that time that the old co-father-in-law directed and controlled the whole transaction. In order to avoid conflict, it was also in the interest of Laji to keep this secret.

Laji, however-since he regarded the demand of $\$ 30,000$ to be excessive and 
unjustified-visited his old co-father-in-law only two and half months after he took possession of the beaker, thereby making the conflict worse. The old co-father-in-law was so enraged by Laji's procrastination that he swore he would not take a single dollar from the mita. In fact, many Roma interpreted Laji's procrastination as lack of respect and appreciation for the old co-fatherin-law - an act of symbolic devaluation and humiliation. Furthermore, Laji's absence strengthened what many suspected; the old co-father-in-law did not play as important role in the transaction as those involved would want them to believe. According to the recollection of one of Laji's uncles, the old co-father-in-law commented Laji's procrastination with the following words: "is your nephew [Laji] mocking us for 2-3 months? Should I go for the mita? Am I such a person? Should I go to beg? Should I go there, begging at his gate? That's what he wants?!?" (communication to the author September 6, 2008). In fact, the old co-father-in-law, to demonstrate his own outstanding social prestige and influence, expected most of his friends and relatives to bring his mita personally to his home. However, the general practice among the Gabors is for the person wishing to receive a mita to approach the person having the "great joy" (the purchaser of a beaker or tankard, someone who secured a marriage alliance, etc.), or to congratulate him at a chance encounter and ask for a mita. The fact that the old co-father-in-law referred to this practice as "begging" symbolically devaluated it while emphasizing his own distinguished social prestige. Laji and his father finally distributed only $\$ 12,000$, not $\$ 30,000$ mita in the home of the old co-father-in-law.

Not long after, Laji and his father contacted a smaller group of Gabor men in Mureş County, who-accompanied by some other witnesses-went with them to the town next to the Hungarian border on May 30th. Since these men in part "live on mita [cash gifts-sometimes extorted-from other Gabor Roma]," Laji and his father distributed almost \$20,000 among them partly as payment for their work as witnesses and partly to preclude a future conflict with them because of their omission of the mita payment or the inadequacy of the cash gift.

Laji's uncle, who had a key role as a broker in organising the transaction, was given only $\$ 2,000$ as mita and even this payment had to wait until a year after the closing of the deal. Also, only half of this sum was given to him in cash and the rest in "goods," For instance, he received clothing (suits, trousers, etc.) worth $\$ 1,000$ from Laji, which he had to sell himself on the markets of Cluj County to "turn them into money."

The highly respectable and successful Gabor man who is now considered to be the village leader in a settlement in Romania with one of the most populous Gabor community visited Laji's home in Cluj County in late 2008. He was then-more than two years after the sale-given his mita $(3,000$ new Romanian lei $=\$ 993)$. As a representation of friendship, the influential guest gave 500 new Romanian lei to Laji's uncle who participated in the transaction as a broker and was present at the time of the visit. (It is common practice for the recipient of a mita given "in return" for good wishes to pass on some of his/her cash gift to a favorite grandchild, close friend, etc.)

According to their estimates, Laji and his father distributed more than $\$ 50,000$ of mita interpreted as an "expression of joy" following the transaction. One of their close relatives once remarked, however, that even so, not all of the deserving, influential Gabor men received mita, although "if you do not give mita, your fair will not resonate [the transaction will not bring the desired 
amount of social fame]." This phrase refers to the fact that the distribution of mita is an important means of fame management. This is primarily because according to Gabor Roma business ethics, it is the moral duty of a person accepting a mita given as an "expression of joy" representing respect or social closeness to "raise" the value and fame of the newly purchased object in public discourses and thereby contribute to the increase of the new owner's prestige. (Or, if the recipient is not willing to do so, he should at least refrain from the symbolic devaluation of the transaction.)

The cost of this entire transaction (purchase price, interest paid on loans, distributed cash gifts, food and drink, etc.) was about $\$ 500,000$ according to Laji's estimate. In the words of Laji's father, "it was a difficult sale, difficult all the way till it was closed. Six months, seven months, almost a year till it was closed [from the beginning of price negotiations to taking the beaker home]" (communication to the author September 3, 2008).

\section{The Aftermath: The Impact of the Beaker Transaction on the Politics of Marriage}

Although Laji, his old co-father-in-law, and their family members tried to keep the old co-fatherin-law's absence from the price bargaining secret, Mate let others know. Mate's motivation was clear: revenge on Laji's father for his wife's adultery and the shame coming from it, as well as his anger over losing the beaker. The old co-father-in-law was humiliated and his prestige tarnished when it became well known that his services as a broker were not used in the price bargaining, and that any rumors to the contrary were only attempts at face-saving. The conflict between Laji and his old co-father-in-law was only worsened by the disagreement over the mita, that is, that Laji gave him less mita than he expected, and even this was taken to him much later than promised. These three elements of the transaction became a source of conflict because they were interpreted as questioning the social prestige of the old co-father-in-law and his expertise as a broker.

Finally, the conflict relating to the purchase of the beaker greatly contributed to the fact that Laji's daughter, married to one of the old co-father-in-law's grandchildren in the winter of 20022003, was sent home in early 2007, ending the marriage and hence, the marriage alliance with Laji. (The $\$ 100,000$ marriage payment was also returned to Laji some months after the divorce.) In order to avoid even greater shame, the family of the old co-father-in-law justified sending the young wife home not by the grievances suffered in the course of the prestige-object transaction, but by the fact that in the years of the young couple's marriage they did not conceive a child. This is a worrying fact according to the Gabor Roma ideology of marriage and biological reproduction, and reason enough for divorce.

\section{Conclusion: Patina- versus Fashion- or Novelty-oriented Prestige Goods among the Romanian Gabor Roma}

So far I have argued that the Gabors' silver objects constitute a group of second-hand commodities, and that the prestige economy developing around them is one of the contemporary 
second-hand cultures based on patina-oriented consumption, similar to other economies of inalienable possessions (family heirlooms, etc.) or communities of competing collectors specialized in personal belongings of celebrities (Cheetham 2009; Giloi 2011; Gregson and Crewe 2003; Lastovicka and Fernandez 2005; Newman et al. 2011). The presented object biography clearly demonstrated how second-handedness and ownership histories of silver prestige objects are constructed through various ideologies and practices-including sale, inheritance, economic brokerage, and proprietary contests - among the Gabor Roma.

As to the ownership history of these objects, the Gabors use both the strategies of fashion- or novelty-oriented and patina-seeking consumption - the relationship of the two is organized along ethnic lines. As I have pointed out elsewhere (Berta 2009), regarding the non-Roma ownership history of silver pieces they purchase at antique markets, the Gabor Roma utilize strategies of symbolic emptying and de-personalization (de-ethnicization, de-singularization, etc.): they consciously and deliberately "delete" the former goldsmiths and non-Roma owners from the objects' biography since, in the estimation of the social and economic value of these pieces, they do not consider the non-Gabor Roma period of their ownership history as a source of value. This conscious forgetting - the lack of interest and documentation-is a divestment practice (see McCracken 1986; Gregson and Crewe 2003) which allows the Roma to "fill up" the cultural biography of these objects with the meanings and values they prefer: the series of Gabor Roma possessors, the details of the proprietary contests between them for the more valuable pieces, and so on. The Gabors' attitude towards non-Roma ownership history can be interpreted as a special case of fashion- or novelty-oriented consumption, which - as previously mentioned - defines the ownership history of second-hand commodities as a to be concealed or erased characteristic.

Concerning that section of the object's biography that is related to their own Roma population, however, the Gabors employ the strategy of patina-seeking consumption; they consider the object's Gabor Roma ownership history as one of the most important, desired, valued, and priceincreasing factors. It is primarily the social prestige of the previous Gabor owners that makes potential buyers pay several times more for these pieces than what they would pay for them at the antiques market. As this object biography demonstrates, potential buyers try to acquire the more valuable pieces in order to become an inalienable part of their ownership historyconceived of as an ethnicized pantheon or hall of fame - and to gain significant renown due to the previous owners' social reputation. (The prestige of the former possessors has a positive effect not only on the value of the object, but also on the Romani political significance and successfulness of the current owner.) The social importance of the Gabor Roma ownership history is clearly shown by the fact that silver objects recently purchased at antique markets by their first Gabor owners are referred to by the Gabor Roma with pejorative metaphors such as "arvona taxtaj" ("an orphan silver beaker"), or "na-j le či dad, či dej" ("it has no father or mother"). The economic value of these pieces is far from that of those objects that earlier were in the possession of influential and successful Gabor men and have sought-after material properties.

The Gabor, however, only spend some of their disposable income on patina-oriented silver beakers and roofed tankards. Since the beginning of the post-socialist consumer revolution following the regime change, several costly forms of goods and services that were previously unavailable or of limited availability in Romania have become increasingly popular among the 
Gabor Roma, especially with the generations growing up after 1989. These expensive goods-similarly to silver prestige objects-are perfect for representing wealth through conspicuous consumption, and therefore my conversation partners considered them to be prestige goods. These include, for instance, new and fashionable-mostly Volkswagen and Opel-automobiles and minibuses, newly built family houses with several rooms and expensive domestic appliances exuding wealth, home entertainment products (color television, etc.), mobile phones, and regular visits to fashionable restaurants (McDonald's, etc.) and shopping centres. I shall label these consumer goods and practices post-socialist prestige goods since their mass consumption and their newly acquired popularity are inseparable from the process of postsocialist economic and social transformation.

These two types of prestige goods differ from each other in several respects: in their identity value (ethnicization, etc.), their embeddedness in history, (in)alienability, visual accessibility, singularization, and market availability. While the consumption of post-socialist prestige goods is characterized by fashion or novelty-oriented value attribution, in the case of purchasing and collecting silver beakers and tankards patina-centered value attribution can be regarded as dominant.

Post-socialist prestige goods can be characterized by the following attributes:

1. They are not endowed with an identity value by the Gabor Roma; they are not involved in ethnic or patrilineal identity projects (they are non-ethnicized, etc.).

2. Embeddedness in history (ownership history) is not a source of value, but on the contrary, is a factor decreasing their value and the amount of social prestige and esteem that can be expected from their ownership (who could hope to achieve greater prestige by driving a well-used, worn and battered car?).

3. In their case, temporary possession - "to be alienated"-ness - is the commodities' ideal state. In other words, they are an efficient way of representing economic resources only until a new model of the given type of product appears on the market, at which point the owners make every effort to replace the model in their possession by the latest one.

4. They can be viewed frequently and by many people.

5. They are not or are only slightly singularized mass products, usually having no proper name, unique material properties and well-known cultural biography.

6. They are not a scarce resource: they can usually be purchased at any time, in an unlimited quantity (their purchase is only limited by the buying power of the prospective owner).

The beakers and roofed tankards of the Gabor Rome are, in contrast, patina-oriented prestige goods:

1. They are endowed with multiple identity values: they are important means of the 
construction and materialization of ethnic belonging, and play a significant role in the conceptualization and representation of ethnic and patrilineal past and identity.

2. Their Gabor Roma ownership history-embeddedness in ethnic history-is one of the most important sources of value.

3. The ideal state of the more valuable pieces is inalienability (Weiner 1985; 1992). In other words, owners make every effort to maintain possession of these objects as long as possible.

4. Although the beakers and roofed tankards are common and popular topics of conversation among Gabor men, their owners rarely make them accessible-viewable and touchable-to others. The social life of the objects stored in hidden locations is therefore largely limited to discourses: the dominant medium of object use among the Gabor Roma is not the sight of but talk about these objects.

5. They are intensively singularized: they have their own proper names and cultural biographies, and are made of a unique composition of material properties.

6. They constitute a scarce resource. The more valuable pieces are rarely put up for sale and are done so at unpredictable times. This explains why the news of a sale often triggers an intensive proprietary contest among potential buyers.

According to Weiner, certain things, like the Maori Sacred Cloaks or Kula shells,

are perceived to belong in an inherent way to their original owners. Inalienable possessions are imbued with affective qualities that are expressions of the value an object has when it is kept by its owners and inherited within the same family or descent group. Age adds value, as does the ability to keep the object against all the exigencies that might force a person or a group to release it to others. [Weiner 1985:210]

Inalienable possessions deserve special attention due to the role they play in the construction, reproduction and authenticating of social identities and hierarchies. As Weiner (1985:210) notes, "the primary value of inalienability... is expressed through the power these objects have to define who one is in an historical sense." Weiner examines these goods mostly in social contexts where the legitimation of the elite is based on events or differences rooted in the past (myths, etc.), and thus, where members of the elite must continuously demonstrate their close relationship to this past to reproduce social distance and hierarchies in the present. Weiner (1985:210) argues that inherited, inalienable possessions are interpreted as the materialization and evidence of this relationship - of the interplay and interdependence of the past and present, and as such they acquire political significance. "The object acts as a vehicle for bringing past time into the present, so that the histories of ancestors, titles, or mythological events become an intimate part of a person's present identity" (Weiner 1985:210).

In the case of the Gabor Roma silver prestige objects, their embeddedness in ethnic and family 
history is also an important identity-forming factor. These pieces play a significant role in the conceptualization and materialization of ethnic and patrilineal identity, history and belonging, and have a powerful impact on the (continuous re)evaluation of prestige relations. (As previously discussed, not all silver beakers and tankards change owners through family inheritance; several of them are sold despite the fact that the Gabors consider inheritance the ideal manner of change of ownership in the case of the more valuable pieces.)

There are at least two significant differences between Weiner's examples and the Gabor Roma prestige-object economy: (1) the relationship between a silver object and its previous Roma owners is limited to the "incorporation" of these possessors into the Roma cultural biography/ownership history of the piece. Therefore, these objects do not "belong in an inherent way to their original owners." (2) The Roma beakers and tankards are not connected with any concept of sacredness or "cosmological authentication" (Weiner 1992:4); the social agency attributed to them is of a different nature. The inheritance of a more valuable piece within a family influences the prestige relations between families and patrilines only in that Gabor Roma consider inheritance a materialization of the permanence of high economic status associated with the respective family or patriline. The inheritance of a sought-after silver object does not automatically reproduce the Romani political position of the heir's predecessors, nor does it grant the heir power over others. (As previously mentioned, Gabor Roma are characterized by the dominance of "soft hierarchies." The competition in the symbolic arenas of Romani politics aims at the appropriation of certain honorific titles. Men that have been successful in these arenas and have gained considerable renown can impact social and economic processes using persuasion, if they want to act in accordance to the Roma ethics of sociability.) As a result, inheritance from father to son is given considerable emotional value only by the members of the heir's family or patriline who consider the inherited piece a symbol of their family and patrilineal identity, history, and belonging.

This study ultimately argues that the analysis of the second-hand goods surrounding us and the ownership histories associated with them constitute a complex anthropological perspective, which allows an insight not only into the world of things, but also offers important lessons on the subtle logic and dynamics of the relationships, interactions and interdependence among subjects - their identity projects, consumer value preferences, economic contests or social differences and hierarchies.

\section{Acknowledgments}

I am heavily indebted to Elayne Antalffy, Anna Babarczy, Andrea Szalai, and to two anonymous reviewers for their comments on earlier versions of this paper. I am especially grateful to the editor for his useful suggestions and criticism, as well as for his encouragement. I alone bear responsibility for any errors of fact, interpretation, or judgment. The preparation of this study was made possible by the generous support of the European Commission (Marie Curie Actions: Intra-European Fellowships for Career Development; 628331). 
Museum Anthropology Review 9(1-2) Spring-Fall 2015

\section{Notes}

1. Besides ownership history, other elements of the object biography may, of course, also add to the uniqueness and desirability of a second-hand commodity.

2. Family heirlooms typically change hands through inheritance and therefore their value is only rarely expressed in money.

3. Since April 1998, I have spent more than 32 months carrying out multi-sited anthropological fieldwork in Transylvanian Gabor and Cărhar Roma communities.

4. The Gabor Roma are characterized by patrilocality and ethnic endogamy. Marriage is usually established among girls of 13-14 and boys of 14-16 years old, in the presence of the future couple, their closest relatives, and some invited Gabor Roma, without the church or mayor's office. Fathers and paternal grandfathers primarily choose the bride or groom, and monitor or control the organization of the engagement and wedding. When considering spousal unions, potential marital alliances between families and patrilines and Romani political and other advantages expected from these alliances are mostly emphasized over the personal characteristics or desires of the future husbands and wives. In weddings organized in well-to-do families that I observed between 1998 and 2014 the marriage payment usually ranged from $\$ 10,000-30,000$.

5. The term xanamik (co-father-in-law) is used by the young couple's fathers to refer to each other.

6. The Romani-speaking population known as "the Cărhars" or "Cărhar Roma" is one of the Roma populations living in Romania. Cărhar Roma communities can be found primarily in Sibiu and Braşov Counties. The Cărhars also consider silver beakers and tankards, their most expensive category of (consumer) goods, as symbols of economic prosperity. Cărhar Roma often try to purchase beakers and tankards from the Gabors (if they find the material characteristics of the pieces attractive), and Gabor owners frequently take out large loans from Cărhars, leaving their prestige objects in pawn.

7. This sum was equal to 61.2 times the average gross monthly wage in Romania in 1961.

8. This purchase price was equal to 116.9 times the average gross monthly wage in Romania in 1961.

9. This purchase price was equal to 579 times the average gross monthly wage in Romania in 1982.

10. All persons mentioned in this paper are represented by pseudonyms.

11. This purchase price was equal to 1,215 times the average gross monthly wage in Romania in 2000. 
12. The Gabor Roma regard mita as a sum of money that, depending on the context, can be interpreted as a wage (to a broker, etc.), a success fee, a compensation, a gift given as a representation of gratitude, a gift for persuasion (bribe), or as a gift given as an expression of joy. The mita, regarded as a gift given as an "expression of joy," is usually distributed at weddings and after certain economic transactions - primarily prestige-object sales-in order to share one's joy with the recipients (close relatives, friends, etc.) and thereby materialize such things as sociability, social closeness, and honour. In this study I use the term mita as a synonym of a cash gift defined as a "representation of joy" (apart from the case of those men who in part "live on mita").

13. The term "old co-father-in-law" (phuro xanamik) is used by the young couple's fathers to refer to each others' fathers.

14. This sum was equal to 513.6 times the average gross wage in Romania in December 2002.

15. The conflict between Laji's and Mate's families dates back to the 1980s. It was started by a secret love affair between Laji's father and Mate's wife, which was discovered after a while, and led to the souring of the relations between the two families. This conflict and the shame accompanying it are the main reasons why Mate was so reluctant to sell his beaker to Laji.

16. This purchase price was equal to 213.2 times the average gross monthly wage in Romania in 1985.

17. This purchase price was 531.8 times the average gross wage in Romania in March 2006.

18. This purchase price was equal to 961 times the average gross monthly wage in Romania in 2006.

\section{References Cited}

Appadurai, Arjun

1986 Introduction: Commodities and the Politics of Value. In The Social Life of Things. Commodities in Cultural Perspective. Arjun Appadurai ed. Pp. 3-63. Cambridge: Cambridge University Press.

Belk, Russell W.

1988 Possessions and the Extended Self. Journal of Consumer Research 15(2):139-168.

1995 Collecting in a Consumer Society. London: Routledge. 
Berta, Péter

2009 Materialising Ethnicity: Commodity Fetishism and Symbolic Re-Creation of Objects among the Gabor Roma (Romania). Social Anthropology 17(2):184-197.

Cheetham, Fiona

2009 Out of Control? An Ethnographic Analysis of the Disposal of Collectable Objects through Auction. Journal of Consumer Behaviour 8(6):316-326.

Gell, Alfred

1998 Art and Agency. An Anthropological Theory. Oxford: Clarendon.

Giloi, Eva

2011 Monarchy, Myth, and Material Culture in Germany, 1750-1950. Cambridge: Cambridge University Press.

Gregson, Nicky

2011 Performativity, Corporeality and the Politics of Ship Disposal. Journal of Cultural Economy 4(2):137-156.

Gregson, Nicky and Crewe, Louise

2003 Second-Hand Cultures. Oxford: Berg.

Harrison, Simon

1995 Four Types of Symbolic Conflict. The Journal of the Royal Anthropological Institute. $1(2): 255-272$.

1999 Identity as a Scarce Resource. Social Anthropology 7(3):239-251.

Herrmann, Gretchen M.

2004 Haggling Spoken Here: Gender, Class, and Style in US Garage Sale Bargaining. The Journal of Popular Culture 38(1):55-81.

Hoskins, Janet

1998 Biographical Objects. How Things Tell the Stories of People's Lives. New York: Routledge. 
2006 Agency, Biography and Objects. In Handbook of Material Culture. Chris Tilley, Webb Keane, Susanne Küchler, Mike Rowlands and Patricia Spyer eds. Pp. 74-84. London: Sage.

Kopytoff, Igor

1986 The Cultural Biography of Things: Commoditization as Process. In The Social Life of Things. Commodities in Cultural Perspective. Arjun Appadurai ed. Pp. 64-94. Cambridge: Cambridge University Press.

Lastovicka, John L. and Fernandez, Karen V.

2005 Three Paths to Disposition: The Movement of Meaningful Possessions to Strangers. Journal of Consumer Research 31(4):813-823.

McCracken, Grant

1986 Culture and Consumption: A Theoretical Account of the Structure and Movement of the Cultural Meaning of Consumer Goods. Journal of Consumer Research 13(1):71-84.

Miller, Daniel and Parrott, Fiona

2009 Loss and Material Culture in South London. Journal of the Royal Anthropological Institute 15(3):502-519.

Newman, George E., Gill Diesendruck, and Paul Bloom

2011 Celebrity Contagion and the Value of Objects. Journal of Consumer Research 38(2):215228.

Parsons, Elizabeth and Maclaran, Pauline

2009 "Unpacking Disposal": Introduction to the Special Issue. Journal of Consumer Behaviour 8(6): 301-304.

Setiffi, Francesca

2011 Reflections on the Cultures of the New and the Second Hand in Italy. Italian Sociological Review 1(3):12-20.

Strahilevitz, Michal A. and George Loewenstein

1998 The Effect of Ownership History on the Valuation of Objects. Journal of Consumer Research 25(3):276-289. 
Szalai, Andrea

2014 Ideologies of Social Differentiation among Transylvanian Gabor Roma. Acta Ethnographica Hungarica 59(1):85-112.

Tuan, Yi-Fu

1980 The Significance of the Artifact. Geographical Review 70(4):462-472.

Weiner, Annette B.

1985 Inalienable Wealth. American Ethnologist 12(2):210-227.

1992 Inalienable Possessions: The Paradox of Keeping-While-Giving. Berkeley: University of California Press.

Péter Berta is a Marie Curie Research Fellow at School of Slavonic and East European Studies (Politics and Sociology), University College London. His special research interests are the economic and social practices of Romanian Gabor and Cărhar Roma, with a focus on (prestige) consumption and the politics and materialization of difference.

http://dx.doi.org/10.14434/mar.v9i1-2.12838 